\title{
ANALISIS PENGARUH HARGA SAHAM PERDANA TERHADAP ABNORMAL RETURN YANG DITERIMA INVESTOR STUDI PADA BURSA EFEK INDONESIA
}

\author{
Afriyeni, Doni Marlius \\ Akademi Keuangan dan Perbankan Padang \\ afriyeni@akbpstie.ac.id
}

\begin{abstract}
In this research uses empirical design, the goal is to determine how the effect of the initial public offering of the abnormal return earned by investors on the Stock Exchange went public in the period 2008-2010. This study is a population of all shares of listed companies on the Stock Exchange. The sampling technique used was purposive sampling method based sampling method with a consideration of certain criteria in order to obtain as many as 26 samples. Based on the statistical test results, it can be concluded that the initial public offering and a significant positive effect on abnormal returns earned by investors on the Stock Exchange, which can be seen from the alternative hypothesis is accepted. This means that the average abnormal return earned by investors on the Stock Exchange for the first six weeks of the companies that go public as many as 26 companies will be greater than 0 (zero) or positive. Overall average abnormal return earned by investors is positive, so that the average IPO price of 26 companies that went public in the year 2008 to 2010 is considered low (undervalued) or if the real rate of return higher than the return that expected.
\end{abstract}

Keyword: Abnormal Return, Stock Exchange

\section{PENDAHULUAN}

Investasi merupakan hal yang sangat penting dan berpengaruh terhadap perekonomian suatu negara. Investasi dapat diartikan sebagai komitmen atas sejumlah dana atau sumber daya lainnya yang dilakukan pada saat ini, dengan tujuan untuk memperoleh keuntungan di masa mendatang. Bentuk investasi tersebut dapat berupa real asset dan financial asset. Real asset contohnya, investasi dalam bentuk tanah dan bangunan. Sedangkan financial asset dalam bentuk deposito, Sertifikat Bank Indonesia (SBI), saham, obligasi dan sebagainya. Pemilihan investasi dapat dilakukan dengan mempertimbangkan risiko dan return atas investasi tersebut.

Saham adalah bukti atas kepemilikan dari sebagian perusahaan dan merupakan salah satu bentuk investasi yang banyak diminati oleh investor. Kegiatan perdagangan saham dilakukan di pasar modal yaitu tempat terjadinya transaksi jual beli saham dan di Indonesia dikenal dengan nama Bursa Efek Indonesia (BEI). 
Dalam proses go public sebelum saham diperdagangkan di pasar sekunder terlebih dahulu saham perusahaan dijual di pasar perdana (primary market) yang biasa disebut IPO (Initial Public Offering). Pada saat IPO, umumnya akan ditemukan abnormal return yang positif bagi investor setelah saham-saham tersebut diperdagangkan di pasar sekunder (Husnan : 1996). Dalam Setianingrum dan Suwito (2008 : 84)) keadaan ini menunjukkan bahwa harga saham pada saat IPO relatif lebih murah, sehingga para investor akan memperoleh keuntungan yang relatif besar. Harga saham yang dijual di pasar perdana (saat IPO) telah ditentukan terlebih dahulu, sedangkan harga di pasar sekunder ditentukan oleh mekanisme pasar (penawaran dan permintaan).

Permasalahan yang dihadapi perusahaan di pasar modal, salah satunya adalah penentuan besarnya harga penawaran perdana. Harga saham pada penawaran perdana ditentukan berdasarkan kesepakatan antara emiten dengan underwriter (penjamin emisi). Underwriter dalam hal ini memiliki informasi yang lebih baik mengenai permintaan terhadap saham-saham emiten dibandingkan dengan emiten itu sendiri. Pihak emiten mengharapkan harga jual yang tinggi. Disisi lain, harga yang tinggi akan mempengaruhi respon atau minat calon investor untuk membeli atau memesan saham yang akan ditawarkan. Bila harga terlalu tinggi dan minat investor rendah, besar kemungkinan saham yang ditawarkan akan kurang laku. Akibatnya penjamin emisi (underwriter) harus menanggung resiko atas saham yang tidak terjual dengan harga rendah, sehingga emiten harus menerima harga murah bagi penawaran perdananya, sehingga terjadi underpriced.

Dalam dua mekanisme penentuan harga tersebut sering terjadi perbedaan harga tehadap saham yang sama antara di pasar perdana dan di pasar sekunder. Apabila penentuan harga saham saat IPO secara signifikan lebih rendah dibandingkan dengan harga yang terjadi di pasar sekunder pada hari pertama, maka terjadi apa yang disebut dengan underpricing. Sebaliknya, apabila harga pada saat IPO secara signifikan lebih tinggi dibandingkan dengan harga yang terjadi di pasar sekunder pada hari pertama, gejala ini disebut dengan overpricing .

Sedangkan dalam berinvestasi investor perlu menentukan strategi investasi, khususnya untuk saham, strategi investasi dapat dibagi menjadi dua yaitu strategi aktif dan strategi pasif. Salah satu strategi aktif yang terbukti menguntungkan adalah dengan membeli saham pada penawaran saham perdana (unseasoned offering), di mana investor akan memperoleh abnormal return. Ini disebabkan oleh beberapa faktor yang mempengaruhinya, salah satunya adalah underwriter yang cenderung untuk menjual saham dengan harga yang murah (undervalued) untuk mengurangi risiko tidak laku terjual. Namun bila keputusan investasi didasarkan atas pertimbangan fundamental perusahaan, maka pilihan antara pasar perdana dan pasar sekunder tidak akan membawa perbedaan apapun.

Abnormal return yang diperoleh oleh investor dapat berupa positif maupun negatif. Hal ini dipengaruhi oleh keadaan masing-masing negara dan kondisi pasar modalnya, apakah sedang bergairah (bullish) atau sedang lesu (bearish). Positif disini maksudnya tingkat laba yang lebih tinggi daripada tingkat laba rata-rata pasar, sedangkan negatif adalah tingkat laba yang lebih rendah daripada tingkat laba rata-rata pasar. 
Konsep keuntungan luar biasa (abnormal return) ini adalah keuntungan yang diperoleh investor bila ia membeli saham di pasar perdana dan segera menjual begitu saham tersebut diperdagangkan di pasar sekunder. Pada kenyataannya di pasar modal Indonesia harga saham perdana cenderung lebih tinggi (overvalued).

Menurut Tandelilin (2001:112), pasar yang efisien adalah pasar di mana harga semua sekuritas yang diperdagangkan telah mencerminkan semua informasi yang tersedia. Aspek penting dalam menilai pasar efisien ini adalah seberapa cepat suatu informasi baru diserap oleh pasar yang tercermin dalam penyesuaian menuju harga keseimbangan yang baru.

Berdasarkan penelitian tentang efisiensi pasar, Fama (1970), mengklasifikasikan bentuk pasar yang efisien ke dalam tiga efficient market hypothesis (EMH), yaitu: Efisiensi dalam bentuk lemah (weak form), Efisiensi dalam bentuk setengah kuat (semistrong), dan Efisensi dalam bentuk kuat (strong form). Hal ini berarti pelaku bursa belum dapat mengetahui segala informasi yang dibutuhkan untuk mengevaluasi harga saham perdana. Di BEI informasi yang diterima para investor cenderung dapat dikatakan minim sehingga menyebabkan tingkat likuiditas di pasar modal menjadi rendah.

Berdasarkan hal diatas, maka penelitian ini dilakukan untuk menganalisis pengaruh harga saham perdana terhadap abnormal return yang diterima investor. Dalam penelitian ini di pilih 26 saham yang listing di BEI dalam periode tahun 2008-2010 (enam minggu pertama setelah IPO) sebagai sampel penelitian.

\section{TINJAUAN LITERATUR}

Investasi merupakan pengorbanan yang dilakukan di masa sekarang dengan harapan memperoleh imbalan/keuntungan di masa yang akan datang. Menurut Tandelilin (2001:5), investasi adalah penundaan konsumsi sekarang untuk digunakan di dalam produksi yang efisien selama periode waktu yang tertentu. Sedangkan menurut Darmadji dan Fakhruddin (2001:110), investasi dapat diartikan sebagai suatu komitmen penempatan dana pada satu atau beberapa objek investasi dengan harapan akan mendapatkan keuntungan di masa mendatang. Dengan demikian dapat dikatakan bahwa investasi adalah alokasi dana sekarang pada objek investasi selama periode waktu tertentu untuk mendapatkan keuntungan di masa mendatang. Dalam berinvestasi, investor juga dihadapkan dengan berbagai risiko investasi.

Pasar modal merupakan tempat bertemu antara pembeli dengan penjual dengan risiko untung dan rugi. Menurut Darmadji dan Fakhruddin (2001:1), pasar modal merupakan pasar untuk berbagai instrumen keuangan jangka panjang yang bisa diperjualbelikan, baik dalam bentuk uang ataupun modal sendiri.

Perusahaan yang membutuhkan dana dapat menjual surat berharganya di pasar modal kepada investor yang mempunyai kelebihan dana. Surat berharga yang baru dikeluarkan oleh perusahaan dijual di pasar primer (primary market). Menurut Gitman (1994:35), "The primary market is the one in which new securities are sold". Sedangkan menurut Emery \& Finnerty (1997:79), "Primary market is a market where transaction involves the sale by a firm of newly created 
securities to get additional financing". Jadi pasar primer dapat sebut sebagai pasar di mana sekuritas dijual pertama kalinya untuk menambah modal.

Sebelum menawarkan saham di pasar primer (perdana), perusahaan emiten sebelumnya akan mengeluarkan informasi mengenai perusahaan secara detail (yang disebut prospektus). Prospektus berfungsi untuk memberikan informasi mengenai kondisi perusahaan kepada para calon investor, sehingga dengan adanya informasi tersebut, maka investor akan bisa mengetahui prospek perusahaan di masa datang, dan selanjutnya tertarik untuk membeli sekuritas yang diterbitkan oleh emiten.

Setelah sekuritas tersebut dijual perusahaan di pasar primer, barulah kemudian sekuritas tersebut diperjualbelikan di pasar sekunder. Transaksi yang dilakukan investor di pasar sekunder tidak akan memberikan tambahan dana bagi perusahaan yang menerbitkan sekuritas (emiten), karena transaksi hanya terjadi antar investor, bukan dengan perusahaan.

Saham merupakan bukti kepemilikan atas aset-aset perusahaan. Menurut Koetin (1994:51), saham adalah hak atas sebagian dari suatu perusahaan, misalnya saham dalam suatu perusahaan terbatas; atau suatu bukti penyertaan atau partisipasi dalam modal suatu perusahaan. Sedangkan menurut Darmadji dan Fakhruddin (2001:5), Saham dapat didefinisikan sebagai tanda penyertaan atau pemilikan seseorang atau badan dalam suatu perusahaan atau perseroan terbatas.

Ada dua keuntungan yang diperoleh pemodal dengan membeli atau memiliki saham, yaitu:

a. Dividen, yaitu pembagian keuntungan yang diberikan perusahaan penerbit saham tersebut atas keuntungan yang dihasilkan perusahaan.

b. Capital Gain, yaitu selisih antara harga beli dan harga jual. Capital gain terbentuk dengan adanya aktivitas perdagangan saham di pasar sekunder.

Di samping dua keuntungan tersebut, maka pemegang saham juga dimungkinkan untuk mendapatkan saham bonus (jika ada), yaitu saham yang dibagikan perusahaan kepada para pemegang saham yang diambil dari agio saham.

Kerugian atau risiko yang dihadapi pemodal dengan kepemilikan sahamnya adalah:

a. Tidak Mendapat Dividen.

b. Capital Loss, yaitu harga jual saham lebih rendah dari harga beli.

Di samping risiko di atas, seorang pemegang saham juga masih dihadapkan dengan potensi risiko lainnya, yaitu:

a. Perusahaan Bangkrut atau Dilikuidasi

b. Saham Di-delist dari Bursa (Delisting)

c. Saham Di-suspend

\section{Penawaran Saham Perdana}

Penawaran saham perdana adalah penawaran saham perusahaan untuk pertama kalinya. Biasanya perusahaan-perusahaan melakukan penawaran saham perdana (go public) untuk menambah modal atau ekspansi. Menurut Tandelilin (2001:35), go public atau penawaran umum merupakan kegiatan yang dilakukan emiten untuk menjual sekuritas kepada masyarakat, berdasarkan tata cara yang diatur undang-undang dan peraturan pelaksanaannya”. 


\section{Proses Penawaran Saham Perdana}

Dalam melakukan penawaran saham perdana, ada isu yang muncul adalah tipe saham apa yang akan dilempar, berapa harga yang harus ditetapkan untuk selembar sahamnya dan kapan waktunya yang paling tepat. Umumnya perusahaan menyerahkan permasalahan ini ke banker investasi (investment banker) yang mempunyai keahlian dalam penjualan sekuritas. Penjualan saham baru perusahaan yang melibatkan banker investasi ini dijual di pasar primer (primary market).

Proses pencatatan efek di BEI dilakukan setelah pernyataan pendaftaran emisi dinyatakan efektif dan emiten bersama dengan penjamin emisi telah melakukan penawaran umum, maka emiten mengajukan permohonan pencatatan ke bursa sesuai dengan ketentuan pencatatan efek di BEI. BEI melakukan evaluasi berdasarkan persyaratan pencatatan yang telah ditetapkan. Jika memenuhi persyaratan pencatatan, BEI akan memberikan surat persetujuan pencatatan. Emiten membayar biaya pencatatan awal. Bursa mengumumkan pencatatan efek tersebut di bursa efek tersebut mulai tercatat dan dapat diperdagangkan di bursa.

Pada awalnya emiten dan penjamin emisi akan menawarkan sahamnya di pasar perdana dalam masa tertentu, dan untuk selanjutnya diperdagangkan di pasar sekunder. Dalam pasar perdana, saham yang ditawarkan mempunyai harga yang sesuai dengan kesepakatan atau negosiasi antara emiten dan penjamin emisi. Harga ini dikenal dengan sebutan harga perdana. Dalam pasar perdana harga tidak dapat mengalami perubahan baik kenaikan maupun penurunan, tidak seperti pada pasar sekunder. Hal tersebut karena di pasar primer perkembangan harga tidak dapat dipengaruhi oleh aktivitas pasar, di mana persediaan saham yang ditawarkan sesuai dengan rencana yang telah ditetapkan.

Pada pasar sekunder, saham mulai dicatat dan diperdagangkan di bursa. Di pasar sekunder yang melakukan perdagangan adalah para pemegang saham serta para investor lainnya sebagai calon pemegang saham yang baru. Jumlah uang yang berputar dalam pasar sekunder tidak lagi mengalir ke dalam perusahaan yang menerbitkan saham tersebut, akan tetapi berpindah dari pemegang saham yang satu ke pemegang saham yang lain. Pada saat inilah harga dari saham-saham tersebut mengalami perubahan atau fluktuasi sesuai dengan permintaan dan penawaran saham yang bersangkutan.

Pendekatan yang akan digunakan dalam menganalisa harga perdana adalah membandingkan antara tingkat return yang sesungguhnya dengan tingkat return yang diharapkan sehingga :

- Jika tingkat return sesungguhnya > return yang diharapkan, maka saham tersebut dikatakan sebagai saham yang dinilai rendah (undervalued).

- Jika tingkat return sesungguhnya < return yang diharapkan, maka saham tersebut dikatakan sebagai saham yang dinilai tinggi (overvalued).

\section{Pengertian Return}

Return merupakan hasil atau keuntungan yang diperoleh dari investasi. Return dapat dibedakan atas return realisasi yang sudah terjadi dan return ekspektasi yang belum terjadi tetapi yang diharapkan akan terjadi di masa mendatang. Secara total, return terdiri dari capital gain dan dividen.

Rate of return adalah ukuran tingkat perolehan dari suatu investasi yang biasa dinyatakan dengan persentase terhadap nilai investasinya. Untuk investasi 
yang dilakukan dalam bentuk saham, investor memperoleh return yang terdiri dari dividen dan capital gain/loss. Hal ini dikemukakan oleh pendapat Van Horne (1986:33) mengenai rate of return di dalam "The benefit associated with ownership include the cash dividens paid during the year together with any appreciation in market price or capital gain, realized at the end of the year".

Dividen merupakan salah satu bentuk tingkat pengembalian atas investasi yang dilakukan oleh para pemegang saham, jika suatu perusahaan memutuskan untuk membagikan dividen maka setiap pemegang saham berhak atas dividen tersebut. Sedangkan capital gain/loss adalah selisih antara harga jual dengan harga beli. Apabila harga jual lebih tinggi dari harga beli maka dikatakan investor memperoleh capital gain, sebaliknya jika harga jual lebih rendah dari harga beli maka investor dikatakan menderita capital loss.

Dengan demikian rate of return suatu saham adalah persentase capital gain/loss terhadap harga periode awal ditambah dengan persentase dividen terhadap harga awal saham. Hal ini dapat dirumuskan sebagai berikut:

Keterangan:

$$
R=\frac{\left(P_{t}-P_{0}\right)+D}{P_{0}}
$$

$\mathrm{R}=$ Rate of return saham, $\mathrm{P}_{0}=$ Harga saham awal periode

$\mathrm{P}_{\mathrm{t}}=$ Harga saham akhir periode, $\mathrm{D}=$ Nilai dividen yang dibagikan pada periode tersebut

\section{Return Realisasi (Realized Return)}

Return realisasi merupakan tingkat keuntungan sesungguhnya yang diperoleh atas investasi suatu saham. Menurut Emery \& Finnerty (1997:172), "The realized return is the rate of return per dollar invested". Untuk perhitungan tingkat keuntungan sesungguhnya, digunakan formula:

$$
R_{i}=\frac{\left(P_{t}-P_{0}\right)+D}{P_{0}}
$$

Keterangan:

$\mathrm{R}_{\mathrm{i}}=$ Return sesungguhnya untuk sekuritas ke-i, $\mathrm{P}_{0}=$ Harga saham awal periode

$\mathrm{P}_{\mathrm{t}}=$ Harga saham akhir periode, $\mathrm{D}=$ Nilai dividen yang dibagikan pada periode tersebut

Return realisasi tidak lain merupakan penjumlahan antara dividen dan capital gain. Return realisasi ini dihitung berdasarkan data historis. Return realisasi dianggap penting karena digunakan sebagai salah satu pengukur kinerja dari perusahaan.

\section{Return Ekspektasi (Expected Return)}

Menurut Ross, Westerfield \& Jeffrey F. Jaffle (1990:256) expected return is the return that an individual expects a stock to earn over the next period. Sedangkan menurut Fred J. Weston : The mean of average return is defined as probability of observing each rate of return (pi), multiplied by the rate of return (Ri), and then summed accros all possible returns".

Adapun persamaan untuk expected return adalah: 


$$
E\left(R_{i}\right)=\sum_{j=1}^{n} R_{i j} P_{i j}
$$

Keterangan:

$$
\begin{array}{ll}
\mathrm{E}\left(\mathrm{R}_{\mathrm{i}}\right) & =\text { return ekspektasi dari suatu sekuritas ke-i } \\
\mathrm{R}_{\mathrm{ij}} & =\text { retur ke-j untuk sekuritas ke-i yang mungkin terjadi } \\
\mathrm{P}_{\mathrm{ij}} & =\text { probabilitas kejadian return ke-j untuk sekuritas ke-i } \\
\mathrm{n} & =\text { banyaknya return yang mungkin terjadi }
\end{array}
$$

Sehingga terlihat bahwa keuntungan yang diharapkan (expected return) merupakan bobot rata-rata hasil yang diharapkan dari saham yang dipilih untuk investasi, yang tentunya kontribusi untuk setiap saham ini tergantung kepada hasil yang diharapkan dari saham yang diinvestasikan.

Tingkat ketidakpastian akan selalu ada, sehingga para investor hanya dapat mengharapkan kepada tingkat keuntungan yang mungkin diperoleh. Ketidakpastian (risiko) investasi tersebut tergantung pada penyebaran nilai tingkat keuntungan di sekitar nilai tingkat keuntungan yang diharapkan.

Return dari saham mengandung unsur ketidakpastian, baik yang menyangkut dividen maupun capital gain. Pemegang saham hanya dapat memperkirakan besarnya return yang akan diterima di masa yang akan datang, di mana perkiraan tersebut belum tentu tepat karena return suatu investasi tidak lain berupa suatu harapan atau ekspektasi, maka keputusan-keputusan investasi lebih sering didasarkan pada expected valuelexpected return.

\section{Return Tidak Normal (Abnormal Return)}

Setelah diuraikan dan dijelaskan mengenai tingkat keuntungan sesungguhnya serta tingkat keuntungan yang diharapkan, maka selanjutnya akan diuraikan tentang pengertian dari abnormal return sebagai variabel terhadap pengujian ini.

Menurut Husnan (1994:125) abnormal return adalah selisih antara tingkat keuntungan yang sesungguhnya dengan tingkat keuntungan yang diharapkan. Rumusannya adalah:

Keterangan:

$$
\mathrm{AR}_{\mathrm{i}}=\mathrm{R}_{\mathrm{i}}-\mathrm{E}\left(\mathrm{R}_{\mathrm{i}}\right)
$$

$\mathrm{AR}_{\mathrm{i}}=$ tingkat return tidak normal sekuritas $\mathrm{i}$

$\mathrm{R}_{\mathrm{i}} \quad=$ return sekuritas $\mathrm{i}$

$\mathrm{E}\left(\mathrm{R}_{\mathrm{i}}\right)=$ return yang diharapkan pada sekuritas $\mathrm{i}$ dengan menggunakan model keseimbangan

Melalui bursa efek, para investor berusaha untuk mendapatkan tingkat keuntungan riil lebih besar dari keuntungan yang diharapkannya setelah memperhitungkan faktor risiko yang kemungkinan ada pada saham yang menjadi alternatif pilihannya. Dengan pendekatan abnormal return ini kita dapat melihat apakah harga saham perdana yang ditawarkan menunjukkan nilai yang terlalu tinggi (overvalue) atau terlalu rendah (undervalue).

\section{Hubungan antara Harga Saham Perdana dengan Abnormal Return}

Harga saham perdana yang disepakati antara emiten dan underwriter akan berpengaruh terhadap abnormal return. Patokan harga saham perdana yang dinilai rendah akan mengakibatkan abnormal return yang diperoleh oleh investor 
menjadi besar (positif) dan sebaliknya jika dinilai tinggi maka abnormal return yang diperoleh akan negatif.

\section{Hipotesis}

Hipotesis dalam penelitian ini yaitu diduga bahwa terdapat pengaruh harga saham perdana terhadap abnormal return.

\section{METODE PENELITIAN}

Penelitian ini menggunakan disain empiris, yang tujuannya adalah melakukan penyelidikan untuk mengetahui bagaimana pengaruh penawaran saham perdana terhadap abnormal return yang diterima oleh investor di BEI.

Populasi dan Sampel

Populasi dari penelitian ini adalah seluruh saham perusahaan yang terdaftar di BEI. Teknik pengambilan sampel yang digunakan adalah metode purposive sampling yaitu metode pengambilan sampel berdasarkan kriteria dengan suatu pertimbangan tertentu. Kriteria tersebut adalah:

a. Saham perusahaan yang telah terdaftar yang melakukan IPO (Initial Public Offering).

b. Penawaran saham perdana yang dilakukan pada tahun 2008-2010 (enam minggu pertama setelah IPO).

Jumlah sampel yang digunakan pada penelitian ini berdasarkan kriteria di atas adalah 26 saham periode tahun 2008-2010 (enam minggu pertama setelah IPO).

\section{Definisi dan Pengukuran Variabel}

Adapun variabel yang digunakan dalam penelitian ini adalah harga saham perdana sebagai variabel independen dan abnormal return sebagai variabel dependen.

Definisi dari variabel yang digunakan adalah:

a. Harga Saham Perdana

Harga saham perdana merupakan harga yang dikeluarkan oleh emiten untuk perlembar saham berdasarkan hasil kesepakatan antara emiten dengan underwriter. Harga saham yang dimaksud adalah harga saham pada penawaran perdana di pasar primer.

b. Abnormal Return

Abnormal return adalah selisih antara tingkat keuntungan yang sesungguhnya dengan tingkat keuntungan yang diharapkan. Adapun rumusannya adalah sebagai berikut:

Keterangan:

$$
\mathrm{AR}_{\mathrm{i}}=\mathrm{R}_{\mathrm{i}}-\mathrm{E}\left(\mathrm{R}_{\mathrm{i}}\right)
$$

$\mathrm{AR}_{\mathrm{i}}=$ tingkat return tidak normal sekuritas $\mathrm{I}, \mathrm{R}_{\mathrm{i}}=$ return sekuritas $\mathrm{i}$

$\mathrm{E}\left(\mathrm{R}_{\mathrm{i}}\right)=$ return yang diharapkan pada sekuritas $\mathrm{i}$

\section{Analisis Data}

Langkah-langkah yang dilakukan dalam analisis data adalah sebagai berikut :

a. Analisa kuantitatif

Adapun rumus yang digunakan adalah sebagai berikut:

$$
\mathrm{Ri}=\sum \underline{\text { Harga akhir }- \text { Harga awal }}: \mathrm{T}-1
$$

Harga awal 


$$
\mathrm{R}_{\mathrm{m}}=\sum \frac{\text { IHSG akhir }- \text { IHSG awal }}{\text { IHSG awal }}: \mathrm{T}-1
$$

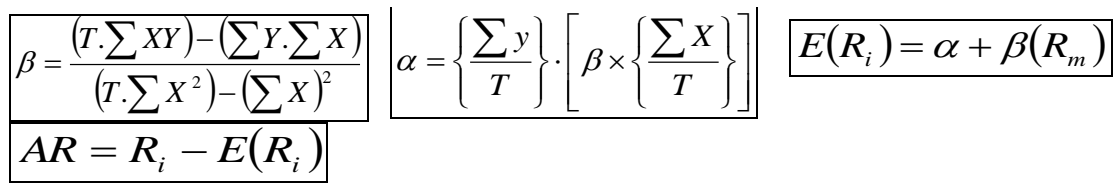

\section{Keterangan:}

$\mathrm{R}_{\mathrm{i}}=$ Nilai keuntungan yang sesungguhnya, $\mathrm{R}_{\mathrm{m}}=$ Tingkat keuntungan indeks pasar

$\beta=$ Koefisien slope yang merupakan beta dari sekuritas

$\alpha=$ Intercept untuk sekuritas, $\mathrm{E}\left(\mathrm{R}_{\mathrm{i}}\right)=$ Keuntungan yang diharapkan

$\mathrm{AR}=$ Abnormal return, $\mathrm{T}=$ Banyaknya hari perdagangan

$\mathrm{X}=$ Perubahan harga saham, $\mathrm{Y}=$ Perubahan IHSG

b. Pengujian hipotesis

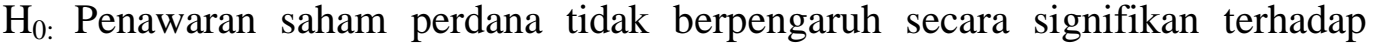
abnormal return.

$\mathrm{H}_{\mathrm{a}}$ : Penawaran saham perdana berpengaruh secara signifikan terhadap abnormal return.

Rumusan untuk uji $t$-student statistic: $\quad T=\frac{\bar{X}-\mu}{S / \sqrt{n}}$

Keterangan: $\quad \bar{X}=1 / n \times \sum X_{i} \quad S=\sqrt{\frac{n \sum X_{i}{ }^{2}-\left(\sum X_{i}\right)^{2}}{n(n-1)}}$

Simbol atau notasi-notasi dalam rumusan tersebut, secara naratif mengandung arti sebagai berikut:

$\bar{X}=$ Rata-rata abnormal return dari 26 saham perusahaan yang go public pada periode tahun 2008-2010 (enam minggu pertama setelah IPO)

$\mathrm{X}_{\mathrm{i}}=$ Rata-rata abnormal return dari tiap saham perusahaan yang go public pada periode tahun 2008-2010 (enam minggu pertama setelah IPO)

$\mu=$ Rata-rata populasi yaitu 0 (nol)

$\mathrm{n}=$ Jumlah perusahaan yang terpilih sebagai sampel yaitu 26 perusahaan

$\mathrm{S}=$ Standar deviasi dari 26 saham perusahaan yang go public pada periode tahun 2008-2010 (enam minggu pertama setelah IPO)

$\mathrm{DF}=$ Degree of Freedom (n-1)

Keputusan untuk menolak atau menerima hipotesis 0 (nol) didasarkan atas informasi yang ada di dalam sampel yang ditarik dari populasi yang diamati. Dalam pengujian ini penulis menggunakan tingkat kepercayaan sebesar 95\%, atau taraf nyata (level of significance) sebesar 0.05 (5\%).

Untuk pengujian hipotesis yang digunakan adalah uji pihak kiri dengan menggunakan student statistic. Dari uji ini, maka dapat ditentukan daerah penerimaan dan penolakan. Jika t-hitung $>\mathrm{t}$-tabel, maka terdapat pengaruh yang signifikan antara harga penawaran saham perdana dengan abnormal return dan hipotesa alternatif penelitian diterima. Sebaliknya jika t-hitung $<$ t-tabel maka tidak terdapat pengaruh yang signifikan antara harga penawaran saham perdana dengan abnormal return dan hipotesa alternatif ditolak. 


\section{PEMBAHASAN \\ Deskriptif Data}

Tabel 1.

Emiten-emiten yang menjadi objek penelitian

\begin{tabular}{|c|c|c|c|c|c|}
\hline No. & Nama Perusahaan & Tgl Listing & $\begin{array}{c}\text { Jumlah Emisi } \\
\text { Saham }\end{array}$ & $\begin{array}{l}\text { Nilai Nominal } \\
(R p)\end{array}$ & Nilai Emisi Saham (Rp) \\
\hline 1. & Arona Binasejati Tbk & 30 April 2008 & 95.000 .000 & 650 & 61.750 .000 .000 \\
\hline 2. & Pelayaran Tempuran Emas Tbk & 9 Juli 2008 & 55.000 .000 & 550 & 30.250 .000 .000 \\
\hline 3. & Bank Mandiri (Persero) Tbk & 14 Juli 2008 & 2.900 .000 .000 & 675 & 1.957.500.000.000 \\
\hline 4. & Bank Rakyat Indonesia (Persero) Tbk & 10 Nov 2008 & 4.764 .705 .000 & 875 & 4.169 .117 .000 .000 \\
\hline 5. & Perusahaan Gas Negara (Persero) Tbk & 15 Des 2008 & 1.685 .185 .000 & 1.500 & 2.527 .778 .000 .000 \\
\hline 6. & Asuransi Jasa Tania Tbk & 29 Des 2008 & 50.000 .000 & 300 & 15.000 .000 .000 \\
\hline 7. & Adhi Karya (Persero) Tbk & 18 Maret 2009 & 441.320 .000 & 150 & 66.198 .000 .000 \\
\hline 8. & Adira Dinamika Multi Finance Tbk & 31 Maret 2009 & 100.000 .000 & 2.325 & 232.500 .000 .000 \\
\hline 9. & Hortus Danavest Tbk & 12 April 2009 & 125.000 .000 & 210 & 26.250 .000 .000 \\
\hline 10. & Bumi Teknokultura Unggul Tbk & 14 Mei 2009 & 120.000 .000 & 125 & 15.000 .000 .000 \\
\hline 11. & Energi Mega Persada Tbk & 07 Juni 2009 & 2.847 .433 .500 & 160 & 455.589 .000 .000 \\
\hline 12. & Pembangunan Jaya Ancol Tbk & 02 Juli 2009 & 799.999 .998 & 1.025 & 820.000 .000 .000 \\
\hline 13. & Sanex Qianjiang Motor Intern'l Tbk & 15 Juli 2009 & 120.000 .000 & 250 & 30.000 .000 .000 \\
\hline 14. & Indosiar Karya Media Tbk & 04 Okt 2009 & 1.989 .163 .103 & 551 & 1.096 .029 .000 .000 \\
\hline 15. & Aneka Kemasindo Utama Tbk & 01 Nov 2009 & 80.000 .000 & 220 & 17.600 .000 .000 \\
\hline 16. & Mitra Adiperkasa Tbk & 10 Nov 2009 & 500.000 .000 & 625 & 312.500 .000 .000 \\
\hline 17. & Yulie Sekurindo Tbk & 10 Des 2009 & 120.000 .000 & 215 & 25.800 .000 .000 \\
\hline 18. & Wahana Ottomitra Multiartha Tbk & 13 Des 2009 & 200.000 .000 & 700 & 140.000 .000 .000 \\
\hline 19. & Multistrada Arah Sarana Tbk & 09 Juni 2010 & 1.000 .000 .000 & 170 & 170.000 .000 .000 \\
\hline 20. & Arpeni Pratama Ocean Line Tbk & 22 Juni 2010 & 500.000 .000 & 625 & 312.500 .000 .000 \\
\hline 21. & Panca Global Securities Tbk & 24 Juni 2010 & 190.000 .000 & 105 & 19.950 .000 .000 \\
\hline 22. & Reliance Securities Tbk & 13 Juli 2010 & 200.000 .000 & 250 & 50.000 .000 .000 \\
\hline 23. & Mandala Multifinance Tbk & 16 Juli 2010 & 325.000 .000 & 195 & 63.375 .000 .000 \\
\hline 24. & Excelcomindo Pratama Tbk & 29 Juli 2010 & 1.427 .500 .000 & 2.000 & 2.855 .000 .000 .000 \\
\hline 25. & Multi Indocitra Tbk & 21 Agus 2010 & 100.000 .000 & 490 & 490.000 .000 .000 \\
\hline 26. & Asuransi Multi Artha Guna Tbk & 23 Agus 2010 & 240.000 .000 & 105 & 25.200 .000 .000 \\
\hline
\end{tabular}

Sumber : www.idx.co.id dan data diolah

\section{Return Realisasi,}

Return realisasi adalah tingkat keuntungan riil yang diterima investor atas dananya yang diinvestasikan pada saham. Keuntungan riil merupakan penjumlahan dari dividen ditambah dengan capital gain. Keuntungan riil dapat dihitung dengan formula sebagai berikut:

$$
\mathrm{Ri}=\sum \frac{\text { Harga akhir }- \text { Harga awal }}{\text { Harga awal }}: \mathrm{T}-1
$$

Keterangan:

$\mathrm{R}_{\mathrm{i}}=$ Nilai keuntungan yang sesungguhnya, $\mathrm{T}=$ Banyaknya hari perdagangan Dalam menghitung tingkat keuntungan riil ini, data yang digunakan adalah harga saham harian selama enam minggu pertama setelah emisi saham di BEI. 
Tabel 2.

Nilai keuntungan riil atas saham perusahaan yang go public pada tahun 2008-2010 (enam minggu pertama setelah IPO)

\begin{tabular}{|c|c|c|c|}
\hline No. & Kode & Nama Perusahaan & Ri \\
\hline 1 & ARTI & Arona Binasejati Tbk & 0.0028134 \\
\hline 2 & TMAS & Pelayaran Tempuran Emas Tbk & -0.0013112 \\
\hline 3 & BMRI & Bank Mandiri (Persero) Tbk & 0.0089012 \\
\hline 4 & BBRI & Bank Rakyat Indonesia (Persero) Tbk & 0.0131887 \\
\hline 5 & PGAS & Perusahaan Gas Negara (Persero) Tbk & 0.0023952 \\
\hline 6 & ASJT & Asuransi Jasa Tania Tbk & 0.0133069 \\
\hline 7 & $\mathrm{ADHI}$ & Adhi Karya (Persero) Tbk & 0.0388178 \\
\hline 8 & ADMF & Adira Dinamika Multi Finance Tbk & -0.0009634 \\
\hline 9 & HADE & Hortus Danavest Tbk & -0.0085396 \\
\hline 10 & BTEK & Bumi Teknokultura Unggul Tbk & 0.0279731 \\
\hline 11 & ENRG & Energi Mega Persada Tbk & 0.0288087 \\
\hline 12 & PJAA & Pembangunan Jaya Ancol Tbk & -0.0033365 \\
\hline 13 & SQMI & Sanex Qianjiang Motor International Tbk & 0.0001554 \\
\hline 14 & IDKM & Indosiar karya Media Tbk & 0.0078109 \\
\hline 15 & AKKU & Aneka Kemasindo Utama Tbk & -0.0100196 \\
\hline 16 & MAPI & Mitra Adiperkasa Tbk & 0.0056845 \\
\hline 17 & YULE & Yulie Sekurindo Tbk & -0.0063205 \\
\hline 18 & WOMF & Wahana Ottomitra Multiartha Tbk & 0.0021369 \\
\hline 19 & MASA & Multistrada Arah Sarana Tbk & 0.0032464 \\
\hline 20 & APOL & Arpeni Pratama Ocean Line Tbk & 0.0041294 \\
\hline 21 & PEGE & Panca Global Securities Tbk & 0.0139606 \\
\hline 22 & RELI & Reliance Securities Tbk & 0.0001031 \\
\hline 23 & MFIN & Mandala Multifinance Tbk & -0.0136933 \\
\hline 24 & EXCL & Excelcomindo Pratama Tbk & 0.0099264 \\
\hline 25 & MICE & Multi Indocitra Tbk & 0.0166366 \\
\hline 26 & AMAG & Asuransi Multi Artha Guna Tbk & -0.0011893 \\
\hline
\end{tabular}

Sumber : www.idx.co.id dan data diolah

Dari tabel di atas dapat disimpulkan bahwa perusahaan yang tingkat keuntungan sesungguhnya $(R i)$ yang bernilai positif berarti investor dari perusahaan ini akan memperoleh keuntungan (capital gain) dan sebaliknya untuk perusahaan yang nilai $R i$-nya negative berarti investor dari perusahaan ini mengalami kerugian (capital loss).

Tingkat Keuntungan Pasar (Rm)

Perhitungan tingkat keuntungan pasar dinyatakan dalam angka IHSG (Indeks Harga Saham Gabungan). Tingkat keuntungan pasar dapat dihitung dengan menggunakan formula sebagai berikut:

$$
\mathrm{R}_{\mathrm{m}}=\sum \underline{\text { IHSG akhir - IHSG awal }}: \mathrm{T}-1
$$

\section{IHSG awal}

Keterangan:

$\mathrm{R}_{\mathrm{m}}=$ Tingkat keuntungan indeks pasar, $\mathrm{T}=$ Banyaknya hari perdagangan 
Tabel 3.

Tingkat keuntungan pasar atas saham-saham perusahaan yang go public pada tahun 2008-2010 (enam minggu pertama setelah IPO)

\begin{tabular}{|c|c|l|c|}
\hline No. & Kode & \multicolumn{1}{|c|}{ Nama Perusahaan } & Rm \\
\hline 1 & ARTI & Arona Binasejati Tbk & 0.0047285 \\
\hline 2 & TMAS & Pelayaran Tempuran Emas Tbk & 0.0000786 \\
\hline 3 & BMRI & Bank Mandiri (Persero) Tbk & 0.0003385 \\
\hline 4 & BBRI & Bank Rakyat Indonesia (Persero) Tbk & -0.0015969 \\
\hline 5 & PGAS & Perusahaan Gas Negara (Persero) Tbk & 0.0036513 \\
\hline 6 & ASJT & Asuransi Jasa Tania Tbk & 0.0041312 \\
\hline 7 & ADHI & Adhi Karya (Persero) Tbk & 0.0011972 \\
\hline 8 & ADMF & Adira Dinamika Multi Finance Tbk & -0.0029327 \\
\hline 9 & HADE & Hortus Danavest Tbk & -0.0019426 \\
\hline 10 & BTEK & Bumi Teknokultura Unggul Tbk & 0.0001815 \\
\hline 11 & ENRG & Energi Mega Persada Tbk & 0.0026190 \\
\hline 12 & PJAA & Pembangunan Jaya Ancol Tbk & 0.0003516 \\
\hline 13 & SQMI & Sanex Qianjiang Motor International Tbk & 0.0000913 \\
\hline 14 & IDKM & Indosiar karya Media Tbk & 0.0031538 \\
\hline 15 & AKKU & Aneka Kemasindo Utama Tbk & 0.0038403 \\
\hline 16 & MAPI & Mitra Adiperkasa Tbk & 0.0028973 \\
\hline 17 & YULE & Yulie Sekurindo Tbk & 0.0031560 \\
\hline 18 & WOMF & Wahana Ottomitra Multiartha Tbk & 0.0037294 \\
\hline 19 & MASA & Multistrada Arah Sarana Tbk & 0.0019062 \\
\hline 20 & APOL & Arpeni Pratama Ocean Line Tbk & 0.0016751 \\
\hline 21 & PEGE & Panca Global Securities Tbk & 0.0011381 \\
\hline 22 & RELI & Reliance Securities Tbk & -0.0020838 \\
\hline 23 & MFIN & Mandala Multifinance Tbk & 0.0014625 \\
\hline 24 & EXCL & Excelcomindo Pratama Tbk & -0.0004372 \\
\hline 25 & MICE & Multi Indocitra Tbk & 0.0027906 \\
\hline 26 & AMAG & Asuransi Multi Artha Guna Tbk & 0.0025210 \\
\hline
\end{tabular}

Sumber : www.idx.co.id dan data diolah

Nilai Beta ( $\beta)$

Notasi beta memberikan gambaran tentang estimasi kenaikan atau penurunan dari imbalan saham yang bersangkutan. Nilai beta dapat dihitung dengan menggunakan formula sebagai berikut:

$$
\beta=\frac{\left(T \cdot \sum X Y\right)-\left(\sum Y \cdot \sum X\right)}{\left(T \cdot \sum X^{2}\right)-\left(\sum X\right)^{2}}
$$

Keterangan:

$\beta=$ Koefisien slope yang merupakan beta dari sekuritas, $\mathrm{T}=$ hari perdagangan $\mathrm{X}=$ Perubahan harga saham, $\mathrm{Y}=$ Perubahan IHSG 
Tabel 4.

Nilai beta atas saham-saham perusahaan yang go public pada tahun 2008-2010 (enam minggu pertama setelah IPO)

\begin{tabular}{|c|c|c|c|}
\hline No. & Kode & Nama Perusahaan & Beta $(\beta)$ \\
\hline 1 & ARTI & Arona Binasejati Tbk & 0.2598458 \\
\hline 2 & TMAS & Pelayaran Tempuran Emas Tbk & 0.1644497 \\
\hline 3 & BMRI & Bank Mandiri (Persero) Tbk & 0.1128958 \\
\hline 4 & BBRI & Bank Rakyat Indonesia (Persero) Tbk & 0.0643561 \\
\hline 5 & PGAS & Perusahaan Gas Negara (Persero) Tbk & 0.1880839 \\
\hline 6 & ASJT & Asuransi Jasa Tania Tbk & 0.0637871 \\
\hline 7 & $\mathrm{ADHI}$ & Adhi Karya (Persero) Tbk & 0.0177027 \\
\hline 8 & ADMF & Adira Dinamika Multi Finance Tbk & 0.2031961 \\
\hline 9 & HADE & Hortus Danavest Tbk & 0.0013995 \\
\hline 10 & BTEK & Bumi Teknokultura Unggul Tbk & -0.0730586 \\
\hline 11 & ENRG & Energi Mega Persada Tbk & 0.0086041 \\
\hline 12 & PJAA & Pembangunan Jaya Ancol Tbk & -0.0298615 \\
\hline 13 & SQMI & Sanex Qianjiang Motor International Tbk & 0.9987931 \\
\hline 14 & IDKM & Indosiar karya Media Tbk & 0.0270426 \\
\hline 15 & AKKU & Aneka Kemasindo Utama Tbk & 0.0461581 \\
\hline 16 & MAPI & Mitra Adiperkasa Tbk & -0.0474641 \\
\hline 17 & YULE & Yulie Sekurindo Tbk & -0.0055179 \\
\hline 18 & WOMF & Wahana Ottomitra Multiartha Tbk & -0.0630659 \\
\hline 19 & MASA & Multistrada Arah Sarana Tbk & 0.0401901 \\
\hline 20 & APOL & Arpeni Pratama Ocean Line Tbk & 0.0109723 \\
\hline 21 & PEGE & Panca Global Securities Tbk & 0.0130419 \\
\hline 22 & RELI & Reliance Securities Tbk & 0.0279056 \\
\hline 23 & MFIN & Mandala Multifinance Tbk & 0.0674473 \\
\hline 24 & EXCL & Excelcomindo Pratama Tbk & 0.0129246 \\
\hline 25 & MICE & Multi Indocitra Tbk & 0.0096308 \\
\hline 26 & AMAG & Asuransi Multi Artha Guna Tbk & 0.0136428 \\
\hline
\end{tabular}

Sumber : www.idx.co.id dan data diolah.

\section{Nilai Alpha ( $\alpha$ )}

Notasi alpha menunjukkan tingkat keuntungan yang akan diperoleh saham yang bersangkutan jika keadaan pasar tetap. Dengan kata lain alpha adalah imbal hasil (return) yang akan diperoleh investor sebesar alpha dari saham tersebut tersedia, begitu pula sebaliknya. Nilai alpha dapat dihitung dengan menggunakan formula sebagai berikut:

$$
\alpha=\left\{\frac{\sum y}{T}\right\} \cdot\left[\beta \times\left\{\frac{\sum X}{T}\right\}\right]
$$

Keterangan:

$\alpha=$ Intercept untuk sekuritas, $\beta$ =Koefisien slope yang merupakan beta sekuritas

$\mathrm{T}=$ Banyaknya hari perdagangan, $\mathrm{X}=$ Perubahan harga saham, $\mathrm{Y}=$ Perubahan IHSG 
Tabel 5.

Nilai alpha atas saham-saham perusahaan yang go public pada tahun 2008-2010 (enam minggu pertama setelah IPO)

\begin{tabular}{|c|c|c|c|}
\hline No. & Kode & Nama Perusahaan & Alpha $(\alpha)$ \\
\hline 1 & ARTI & Arona Binasejati Tbk & 0.0039974 \\
\hline 2 & TMAS & Pelayaran Tempuran Emas Tbk & 0.0000000 \\
\hline 3 & BMRI & Bank Mandiri (Persero) Tbk & 0.0000003 \\
\hline 4 & BBRI & Bank Rakyat Indonesia (Persero) Tbk & -0.0000014 \\
\hline 5 & PGAS & Perusahaan Gas Negara (Persero) Tbk & 0.0000016 \\
\hline 6 & ASJT & Asuransi Jasa Tania Tbk & 0.0000035 \\
\hline 7 & $\mathrm{ADHI}$ & Adhi Karya (Persero) Tbk & 0.0000008 \\
\hline 8 & ADMF & Adira Dinamika Multi Finance Tbk & 0.0000006 \\
\hline 9 & HADE & Hortus Danavest Tbk & 0.0000000 \\
\hline 10 & BTEK & Bumi Teknokultura Unggul Tbk & -0.0000004 \\
\hline 11 & ENRG & Energi Mega Persada Tbk & 0.0000006 \\
\hline 12 & PJAA & Pembangunan Jaya Ancol Tbk & 0.0000000 \\
\hline 13 & SQMI & Sanex Qianjiang Motor International Tbk & 0.0000000 \\
\hline 14 & IDKM & Indosiar karya Media Tbk & 0.0000007 \\
\hline 15 & AKKU & Aneka Kemasindo Utama Tbk & -0.0000018 \\
\hline 16 & MAPI & Mitra Adiperkasa Tbk & -0.0000008 \\
\hline 17 & YULE & Yulie Sekurindo Tbk & 0.0000001 \\
\hline 18 & WOMF & Wahana Ottomitra Multiartha Tbk & -0.0000005 \\
\hline 19 & MASA & Multistrada Arah Sarana Tbk & 0.0000002 \\
\hline 20 & APOL & Arpeni Pratama Ocean Line Tbk & 0.0000001 \\
\hline 21 & PEGE & Panca Global Securities Tbk & 0.0000002 \\
\hline 22 & RELI & Reliance Securities Tbk & 0.0000000 \\
\hline 23 & MFIN & Mandala Multifinance Tbk & -0.0000014 \\
\hline 24 & EXCL & Excelcomindo Pratama Tbk & -0.0000001 \\
\hline 25 & MICE & Multi Indocitra Tbk & 0.0000004 \\
\hline 26 & AMAG & Asuransi Multi Artha Guna Tbk & 0.0000000 \\
\hline
\end{tabular}

Sumber : www.idx.co.id dan data diolah

\section{Return Ekspektasi}

Dengan formula model indeks tunggal, investor dapat menerapkan perhitungan untuk menghitung berapa tingkat keuntungan yang diharapkan tersebut dengan cukup baik. Keuntungan yang diharapkan atau $\mathrm{E}(\mathrm{Ri})$ dapat dihitung dengan menggunakan formula sebagai berikut:

$$
E\left(R_{i}\right)=\alpha+\beta\left(R_{m}\right)
$$

Keterangan:

$\mathrm{E}\left(\mathrm{R}_{\mathrm{i}}\right)=$ Keuntungan yang diharapkan, $\alpha=$ Intercept untuk sekuritas

$\beta=$ Koefisien slope yang merupakan beta sekuritas, $R_{m}=$ keuntungan indeks pasar 
Tabel 6.

Keuntungan yang diharapkan atas saham-saham perusahaan yang go public pada tahun 2008-2010 (enam minggu pertama setelah IPO)

\begin{tabular}{|c|c|c|c|}
\hline No. & Kode & Nama Perusahaan & $E(R i)$ \\
\hline 1 & ARTI & Arona Binasejati Tbk & 0.0052261 \\
\hline 2 & TMAS & Pelayaran Tempuran Emas Tbk & 0.0000129 \\
\hline 3 & BMRI & Bank Mandiri (Persero) Tbk & 0.0000386 \\
\hline 4 & BBRI & Bank Rakyat Indonesia (Persero) Tbk & -0.0001041 \\
\hline 5 & PGAS & Perusahaan Gas Negara (Persero) Tbk & 0.0006884 \\
\hline 6 & ASJT & Asuransi Jasa Tania Tbk & 0.0002670 \\
\hline 7 & $\mathrm{ADHI}$ & Adhi Karya (Persero) Tbk & 0.0000220 \\
\hline 8 & ADMF & Adira Dinamika Multi Finance Tbk & -0.0005953 \\
\hline 9 & HADE & Hortus Danavest Tbk & -0.0000027 \\
\hline 10 & BTEK & Bumi Teknokultura Unggul Tbk & -0.0000136 \\
\hline 11 & ENRG & Energi Mega Persada Tbk & 0.0000232 \\
\hline 12 & PJAA & Pembangunan Jaya Ancol Tbk & -0.0000105 \\
\hline 13 & SQMI & Sanex Qianjiang Motor International Tbk & 0.0000912 \\
\hline 14 & IDKM & Indosiar karya Media Tbk & 0.0000860 \\
\hline 15 & AKKU & Aneka Kemasindo Utama Tbk & 0.0001755 \\
\hline 16 & MAPI & Mitra Adiperkasa Tbk & -0.0001383 \\
\hline 17 & YULE & Yulie Sekurindo Tbk & -0.0000173 \\
\hline 18 & WOMF & Wahana Ottomitra Multiartha Tbk & -0.0002357 \\
\hline 19 & MASA & Multistrada Arah Sarana Tbk & 0.0000769 \\
\hline 20 & APOL & Arpeni Pratama Ocean Line Tbk & 0.0000185 \\
\hline 21 & PEGE & Panca Global Securities Tbk & 0.0000151 \\
\hline 22 & RELI & Reliance Securities Tbk & -0.0005820 \\
\hline 23 & MFIN & Mandala Multifinance Tbk & 0.0000973 \\
\hline 24 & EXCL & Excelcomindo Pratama Tbk & -0.0000057 \\
\hline 25 & MICE & Multi Indocitra Tbk & 0.0000273 \\
\hline 26 & AMAG & Asuransi Multi Artha Guna Tbk & 0.0000344 \\
\hline
\end{tabular}

Sumber : www.idx.co.id dan data diolah

Dari tabel di atas dapat disimpulkan bahwa perusahaan yang tingkat keuntungan yang diharapkan (expected return-nya) positif, maka investor akan memperoleh keuntungan atas investasinya sebesar $\mathrm{E}(\mathrm{Ri})$ yang terjadi, dan sebaliknya investor akan mengalami kerugian (loss) apabila E(Ri) nya negatif.

Return Tidak Normal

Return tidak normal adalah selisih antara return realisasi dikurangi dengan return ekspektasi. Atau jika dibuat dalam bentuk persamaan matematisnya adalah sebagai berikut:

Keterangan:

$$
A R=R_{i}-E\left(R_{i}\right)
$$

$\mathrm{AR}=$ Abnormal return, $\mathrm{R}_{\mathrm{i}}=$ Nilai keuntungan riil, $\mathrm{E}\left(\mathrm{R}_{\mathrm{i}}\right)=$ Keuntungan yang diharapkan 
Tabel 7.

Return tidak normal atas saham-saham perusahaan yang go public pada tahun 2008-2010 (enam minggu pertama setelah IPO)

\begin{tabular}{|c|c|c|c|c|}
\hline No. & Kode & Nama Perusahaan & AR & $\mathrm{AR}^{2}$ \\
\hline 1 & ARTI & Arona Binasejati Tbk & -0.0024127 & 0.0000058 \\
\hline 2 & TMAS & Pelayaran Tempuran Emas Tbk & -0.0013242 & 0.0000018 \\
\hline 3 & BMRI & Bank Mandiri (Persero) Tbk & 0.0088626 & 0.0000785 \\
\hline 4 & BBRI & Bank Rakyat Indonesia (Persero) Tbk & 0.0132929 & 0.0001767 \\
\hline 5 & PGAS & Perusahaan Gas Negara (Persero) Tbk & 0.0017068 & 0.0000029 \\
\hline 6 & ASJT & Asuransi Jasa Tania Tbk & 0.0130398 & 0.0001700 \\
\hline 7 & $\mathrm{ADHI}$ & Adhi Karya (Persero) Tbk & 0.0387958 & 0.0015051 \\
\hline 8 & ADMF & Adira Dinamika Multi Finance Tbk & -0.0003680 & 0.0000001 \\
\hline 9 & HADE & Hortus Danavest Tbk & -0.0085369 & 0.0000729 \\
\hline 10 & BTEK & Bumi Teknokultura Unggul Tbk & 0.02798678 & 0.0007833 \\
\hline 11 & ENRG & Energi Mega Persada Tbk & 0.0287855 & 0.0008286 \\
\hline 12 & PJAA & Pembangunan Jaya Ancol Tbk & -0.0033261 & 0.0000111 \\
\hline 13 & SQMI & Sanex Qianjiang Motor International Tbk & 0.0000642 & 0.0000000 \\
\hline 14 & IDKM & Indosiar karya Media Tbk & 0.0077249 & 0.0000597 \\
\hline 15 & AKKU & Aneka Kemasindo Utama Tbk & -0.0101951 & 0.0001039 \\
\hline 16 & MAPI & Mitra Adiperkasa Tbk & 0.0058228 & 0.0000339 \\
\hline 17 & YULE & Yulie Sekurindo Tbk & -0.0063031 & 0.0000397 \\
\hline 18 & WOMF & Wahana Ottomitra Multiartha Tbk & 0.0023726 & 0.0000056 \\
\hline 19 & MASA & Multistrada Arah Sarana Tbk & 0.0031696 & 0.0000100 \\
\hline 20 & APOL & Arpeni Pratama Ocean Line Tbk & 0.0041110 & 0.0000169 \\
\hline 21 & PEGE & Panca Global Securities Tbk & 0.0139455 & 0.0001945 \\
\hline 22 & RELI & Reliance Securities Tbk & 0.0001612 & 0.0000000 \\
\hline 23 & MFIN & Mandala Multifinance Tbk & -0.0137906 & 0.0001902 \\
\hline 24 & EXCL & Excelcomindo Pratama Tbk & 0.0099322 & 0.0000986 \\
\hline 25 & MICE & Multi Indocitra Tbk & 0.0166093 & 0.0002759 \\
\hline 26 & AMAG & Asuransi Multi Artha Guna Tbk & -0.0012237 & 0.0000015 \\
\hline \multicolumn{2}{|c|}{ Total } & & 0.1489030 & 0.0046672 \\
\hline \multicolumn{2}{|c|}{ Total Kuadrat } & & 0.0221721 & \\
\hline \multicolumn{2}{|c|}{ Rata-rata } & & 0.0057270 & \\
\hline
\end{tabular}

Sumber : www.idx.co.id dan data diolah

Dari tabel di atas dapat disimpulkan bahwa hasil perhitungan abnormal return dari 26 perusahaan yang go public pada periode tahun 2008-2010 selama enam minggu pertama setelah saham-saham tersebut diperdagangkan di pasar sekunder, ternyata ada 17 perusahaan yang memiliki abnormal return positif selama enam minggu pertama.

Sedangkan saham-saham lainnya memiliki nilai abnormal return negatif selama enam minggu pertama setelah penawaran saham perdana. Yang akan membuat investor merugi jika melakukan investasi pada saham-saham tersebut selama enam minggu pertama setelah penawaran saham perdana. Dan secara keseluruhan nilai rata-rata abnormal return dari 26 perusahaan selama enam minggu pertama setelah penawaran saham perdana adalah 0.0057270 atau 
$0.57270 \%$. Sehingga harga saham perdana dari 26 perusahaan yang go public pada periode tahun 2008-2010 tersebut secara rata-rata dinilai rendah (undervalue).

Pengujian Statistik

Pengujian statistik berdasarkan pada nilai rata-rata return tidak normal keseluruhan yang diperoleh yaitu sebesar 0.005727. Model yang digunakan dalam pengujian ini adalah uji t-statistik. (distribusi t), yang diformulasikan sebagai berikut :

$$
T=\frac{\bar{X}-\mu}{S / \sqrt{n}}
$$

Keterangan :

$\bar{X} \quad=$ Rata-rata abnormal return dari 26 saham perusahaan yang go public pada periode tahun 2008-2010

$\mu \quad=$ Rata-rata populasi yaitu 0 (nol)

$\mathrm{n} \quad=$ Jumlah perusahaan yang terpilih sebagai sampel yaitu 26 perusahaan

$\mathrm{S}=$ Standar deviasi dari 26 saham perusahaan yang go public pada periode tahun 2008-2010

$\mathrm{DF}=$ Degree of Freedom $(\mathrm{n}-1)$

Selanjutnya untuk mencari $\mathrm{S}$, digunakan rumus sebagai berikut :

$S=\frac{n \sum X_{i}^{2}-\left(\sum X_{i}\right)^{2}}{n(n-1)}$

Keterangan : $\mathrm{X}_{\mathrm{i}}^{2}=\Sigma$ kuadrat total, $\left(\Sigma \mathrm{X}_{\mathrm{i}}\right)^{2}=(\Sigma \text { total })^{2}$ $\mathrm{n}=$ Jumlah perusahaan yang terpilih sebagai sampel

Sehingga simpangan baku (S) dapat dihitung sebagai berikut :

$$
\begin{array}{ll}
S=\sqrt{\frac{n \sum X_{i}^{2}-\left(\sum X_{i}\right)^{2}}{n(n-1)}} & S=0.0123522 \\
S=\sqrt{\frac{26(0.0046672)-(0.0221721)}{26(26-1)}} & T=0.0909277 \\
T=\frac{\bar{x}-\mu}{S \sqrt{n}} \quad T=\frac{0.0057270-0}{0.0123522 \sqrt{26}} &
\end{array}
$$

Dari hasil pengujian statistik tersebut dapat disimpulkan bahwa selama enam minggu pertama dengan rata-rata abnormal return sebesar 0.005727 $(0.5727 \%)$, diperoleh hasil pengujian statistik sebesar 0.0909 (jika dibulatkan).

Pengujian Hipotesis

Langkah selanjutnya adalah menentukan apakah hipotesis alternatif (Ha) diterima atau ditolak, yaitu dengan cara membandingkan t-tabel dengan interval kepercayaan yang digunakan sebesar $95 \%$ atau $\alpha=0.05$ dan degree of freedom (df) $=25$ serta pengujian yang digunakan adalah uji pihak kiri, yang menunjukkan nilai sebesar -1.708 dengan t-hitung sebesar 0.0909. Dari hasil perbandingan ini maka dapat dilihat bahwa t-hitung $=0.0909>\mathrm{t}$-tabel $=-1.708$, yang menyatakan bahwa hipotesis alternatif diterima, karena berada pada daerah penerimaan.

Berdasarkan pengujian di atas dapat disimpulkan bahwa penawaran saham perdana berpengaruh positif dan signifikan terhadap abnormal return yang 
diterima oleh investor di BEI, yang mana dapat diketahui dari hipotesis alternatif yang diterima. Ini berarti rata-rata abnormal return yang diterima oleh investor di BEI untuk enam minggu pertama dari perusahaan yang go public sebanyak 26 perusahaan akan lebih besar dari 0 (nol) atau positif. Secara keseluruhan nilai ratarata abnormal return yang diterima oleh investor adalah positif, sehingga rata-rata harga saham perdana dari 26 perusahaan yang go public pada tahun 2008-2010 tersebut adalah dinilai rendah (undervalue) atau jika tingkat return sesungguhnya lebih tinggi dari return yang diharapkan.

\section{PENUTUP}

\section{Kesimpulan}

1. Hasil perhitungan abnormal return dari 26 perusahaan yang go public pada periode tahun 2008-2010 selama enam minggu pertama setelah saham-saham tersebut diperdagangkan di pasar sekunder, ternyata ada 17 perusahaan yang memiliki abnormal return positif selama enam minggu pertama. Sedangkan saham-saham lainnya memiliki nilai abnormal return negatif selama enam minggu pertama setelah penawaran saham perdana. Yang akan membuat investor merugi jika melakukan investasi pada saham-saham tersebut selama enam minggu pertama setelah penawaran saham perdana, sehingga ini mengindikasikan bahwa saham-saham tersebut harga perdananya ketika go public dinilai terlalu tinggi (overvalue).

2. Nilai rata-rata abnormal return dari 26 perusahaan selama enam minggu pertama setelah penawaran saham perdana adalah $0.57270 \%$. Sehingga harga saham perdana dari 26 perusahaan tersebut secara rata-rata dinilai rendah (undervalue).

3. Kondisi pasar modal Indonesia berada dalam bentuk setengah kuat, karena Saran masih adanya abnormal return yang diperoleh oleh investor.

Penelitian selanjutnya lebih baik menggunakan model lain yang lebih representatif dan akurat dalam perhitungannya, karena model pasar memiliki kelemahan dalam menaksir tingkat keuntungan yang diharapkan oleh investor. Hal ini disebabkan return dari harga saham yang bersangkutan dipengaruhi oleh pergerakan pasar. Dalam artian dipengaruhi oleh keadaan pasar sedang bergairah atau lesu. Apabila didorong dengan ketidakstabilan kondisi ekonomi dewasa ini, maka diperlukan model yang dapat mewakili semua kondisi, yang diperlukan dalam proses penelitian lebih lanjut.

\section{DAFTAR PUSTAKA}

Brav, Alon,2000, "Inference in Long Horizon Even Studies : A Bayesian Approach with Appilication to Initial Public Oooerings", Journal Of Finance Vol LV, No. 5, p.1979-2007

Darmadji, Tjiptono dan Hendy M. Fakhruddin, 2001, "Pasar Modal Di Indonesia", Jakarta, Salemba Empat

Elton, Edwin J., 1999 " Expected return, Realized Retun, and Asset Pricing Test", Journal of Finance, Vol.LIV, No.4, p. 1199-1219 
Ficher, Donald E., and Ronald J. Jordan, 1991, "Security Analisis and Portfolio Management", Upper Saddle River, New Jersey, Pretice Hall

Foerster, R Stephen and G Andrew Karolyi, 1999, " The Effects of Market Segmentation and Investor Recognition on Asset : Evidence from Foreign Stocks Listing in the Unted States", Journal of Finance Vol LV, No. 3, p.981-1011

Hanafi, Mamduh, 1998, “Efisiensi Emisi Saham Baru Di Bursa Efek Jakarta ( 1989-1994)", Kelola, No.17/VII, p. 88-105

Horne, James C. Van, 1996, "Financial Managemen and Policy", New Jersey, Prentice Hall

Husnan, Suad, 1994, “Dasar-Dasar Teori Portofolio dan Analisis Sekuritas”, Yogyakarta, UPP-AMP YKPN

Indonesia Stock Exchange, IDX.go.id

Krigman, Laurie, Wayne H. Shaw, and Kent L. Womack, 1999, "The Persistence of IPO and the Predictive Power of Flipping”, Journal of Finance, Vol. Liv, No. 3, p. 1015-1043

M, Jogiyanto H., 2003, "Teori Portofolio dan Analisis Investasi“, Yogyakarta, BPFE

Sharpe, WilliamF.,Gordon J.Alexander, and Jeffrey V. Bailey, 1995, "Investment" Upper Saddle River, New Jersey, Prentice Hall

Tandelilin, Eduardus, 2001, "Analisa Investasi dan Manajemen Portofolio", Yogyakarta, BPFE 